\title{
Development and characterisation of T lymphocyte lines from human small intestinal biopsies
}

\author{
D KELLEHER AND M F KAGNOFF \\ From the University of California, San Diego, School of Medicine, Department of Medicine, La Jolla, CA, \\ USA
}

SUmmary T lymphocyte lines were developed from human small intestinal biopsies obtained at the time of gastroduodenoscopy. Lines were established as outgrowths from biopsy specimens in microculture using a combination of $T$ cell mitogens, indomethacin, interleukin 2 (IL-2) and autologous irradiated feeder cells. The predominant phenotype of $T$ cells after six to 12 weeks in culture was CD2, CD3, and CD4 positive. Functionally, these T cell lines secreted IL-2 in response to stimulation with phytohemagglutinin (PHA) and phorbol 12-myristate 13-acetate (PMA) in combination, but not to PHA or PMA alone. Two to $7 \%$ of cells in each line expressed natural killer (NK) cell-associated markers - that is, Leu 7, CD16, and Leu 19. Moreover, such cells were cytotoxic for NK sensitive targets, but not for NK resistant targets or allogeneic or autologous Epstein Barr Virus (EBV) transformed B cells. Sufficient numbers of small intestinal lymphoid cells for study were previously available only from patients undergoing surgical resections of the small bowel. The ability to isolate and culture human small intestinal $\mathbf{T}$ lymphocytes from gastroscopic intestinal biopsies provides an important new tool for studies of human small intestinal lymphocytes.

T lymphocytes in the human small intestine have been studied using immunohistochemical methods. CD4 bearing T lymphocytes - that is HLA class II restricted $\mathrm{T}$ lymphocytes, predominate in the lamina propria whereas CD8 bearing lymphocytes - that is, HLA class I restricted T lymphocytes, predominate in the intraepithelial region. ${ }^{14}$ The CD4 and CD8 markers correlate with the MHC restriction of $\mathrm{T}$ lymphocytes that usually, but not exclusively, mediate helper/inducer and cytotoxic/suppressor functions respectively. ${ }^{56}$

Functional studies of human small intestinal lymphocytes have been limited as access to large numbers of such cells has been possible only in patients undergoing surgical resection. Further, experiments carried out on small intestinal lymphocytes freshly isolated from surgical specimens have produced conflicting results. For example, it has been controversial whether or not the human intestinal mucosa contains cells that mediate natural killer (NK) activity. ${ }^{7-12}$ Differences in cell separation pro-

Address for correspondence: Dr D Kelleher, Lilly Research Laboratories, La Jolla Facility, 3252 Holiday Court, La Jolla, CA 92037, USA

Accepted for publication 29 September 1988. cedures - that is, enzymatic or mechanical, and the proximity of resected specimens to disease may contribute to the variable results among studies.

We describe herein a system for the initiation and maintenance of human $\mathrm{T}$ lymphocyte lines from small intestinal biopsy specimens obtained at the time of gastroduodenoscopy. In addition, we report on the initial phenotypic and functional characteristics of these cell lines.

\section{Methods}

MONONUCLEAR CELLS

Peripheral blood mononuclear cells (PBMC) were separated from heparinised blood by centrifugation on Ficoll hypaque (Pharmacia Fine Chemicals, Piscataway, NJ) gradients. Peripheral blood mononuclear cells were stored at $-70^{\circ} \mathrm{C}$ in fetal calf serum (FCS) containing $5 \%$ dimethyl sulphoxide, until used as feeder cells.

T CELL LINES

Two to four biopsies, 3-5 $\mathrm{mm}$ in diameter, were obtained from the distal duodenum of each subject at the time of flexible gastroduodenoscopy. Two sub- 
jects (BH, ROPE) had coeliac disease, one had oesophageal carcinoma (ALS), one had antral gastritis $(\mathrm{AH})$, one had a gastric ulcer (EJ), and one was endoscopically and histologically normal (PR). Both coeliac patients had partial villous atrophy on histology. Neither patient was adhering to a strict gluten free diet. Biopsies were placed in complete medium - that is, RPMI 1640 containing penicillin $100 \mathrm{U} / \mathrm{ml}$, streptomycin $100 \mu \mathrm{g} / \mathrm{ml}$ kanamycin 100 $\mu \mathrm{g} / \mathrm{ml}, 5 \times 10^{-5}$ M 2-mercaptoethanol, $2 \mathrm{mM} \mathrm{L-}$ glutamine and Hepes buffer $1 \mathrm{mg} / \mathrm{ml}$, supplemented with $10 \%$ FCS and then divided into small fragments of approximately $2 \mathrm{mM}$ diameter. Each fragment was placed in an individual well of a 96-well U-bottomed microwell plate (Costar) containing $200 \mu \mathrm{l}$ complete medium supplemented with $10 \%$ pooled human serum. Ten micrograms per millilitre PHA (Sigma Chemical Co, St Louis, Mo), $1 \mu \mathrm{g} / \mathrm{ml}$ concanavalin A (Con A) (Calbiochem, La Jolla, CA), and $1 \mu \mathrm{g} / \mathrm{ml}$ indomethacin (Sigma) was added to each well. After three days, $10^{5}$ autologous PBMC, irradiated with 4000R, were added to each well as feeder cells. On day 5 of culture, medium was supplemented with 20\% MLA-144 (American Type Tissue Culture Collection (ATCC), Rockville, MD) supernatant as a source of IL-2, and cells were cultured for an additional five days. On day 10 of culture, biopsy fragments were removed and lymphocytes remaining in the fragments were obtained by agitating through a 21 gauge needle. T cells grew out from $50-60 \%$ of the tissue fragments. Cells were then pooled and cultured for 10 day cycles with irradiated PBMC as feeder cells. PHA, Con A, and indomethacin at the above described doses were added on day 1 , and IL-2 was added on day 5 of the cycle. Lymphocyte viability within individual biopsy fragments was assessed by fluorescence microscopy after staining fragments removed from the microtitre wells with ethidium bromide $10 \mu \mathrm{g} / \mathrm{ml}$ and acridine orange $3 \mu \mathrm{g} / \mathrm{ml}$. Using this protocol, $\mathrm{T}$ cells were cultured for up to 12 weeks continuously. At the end of 12 weeks, the cells continued to proliferate. The limiting factor in further longterm maintenance, however, was the availability of autologous accessory cells as feeder cells. Human subject protocols were approved by the UCSD Committee on Human Subjects.

EBV-TRANSFORMED B CELL LINES

Epstein Barr virus transformed B cell lines (EBVB) were initiated by culturing $\mathrm{PBMC}$ at a concentration of $1 \times 10^{6} / \mathrm{ml}$ in 96 -well flat bottomed tissue culture plates (Costar) with cyclosporin A $2 \mu \mathrm{g} / \mathrm{ml}$ and supernatant from the EBV-shedding line 1437, as previously described. ${ }^{13}$ Histocompatibility locus antigen typing of EBVB was done using a standard microcytotoxicity assay.
Table 1 Antibodies used in these studies

Cluster

Antibody designation Predominant cell type expressing marker

\begin{tabular}{lll}
\hline OKT11 & CD2 & T cells \\
Leu 4 & CD3 & Mature T cells \\
Leu 3a & CD4 & Helper/inducer T cell subset \\
Leu 2a & CD8 & $\begin{array}{l}\text { Suppressor/cytotoxic T cell subset } \\
\text { NK cells and some cells that mediate antibody } \\
\text { dependent cellular cytotoxicity }\end{array}$ \\
& CD16 & $\begin{array}{l}\text { NK cells and some cytotoxic T lymphocytes } \\
\text { Leu 7 }\end{array}$ \\
Leu 19 & & NK cells and some cytotoxic T lymphocytes
\end{tabular}

CELL SURFACE MARKERS ON T CELL LINES Cell surface markers on lymphocytes were determined using the murine monoclonal antibodies Leu 2a, Leu 3a, Leu 4, Leu 7, Leu 11b, Leu 19 (Becton Dickinson, Mountain View, CA), and OKT11 (ATCC). The cluster designation (CD) determinants recognised by these antibodies and the cells on which they are found are listed in Table 1 . Briefly, cells were incubated for 45 minutes at $4^{\circ} \mathrm{C}$ in the presence of murine monoclonal antibody, washed in phosphate buffered saline and then incubated for 45 minutes with fluorescein-isothiocyanate (FITC)-conjugated rabbit antimouse immunoglobulin (Zymed, So, San Francisco, CA). The per cent of positive staining cells was determined by flow cytometry using an Ortho Cytofluorograph system 50-H (Ortho Diagnostics, Westwood, MA) counting 10000 cells. The variability of this assay is less than $5 \%$ for triplicate samples.

\section{PROLIFERATION}

T cells were collected 10 days after the last stimulation with mitogen. Proliferation assays were carried out in triplicate in 96-well U-bottomed plates in 200 $\mu \mathrm{l}$ volumes in complete medium containing $10 \%$ FCS. For the mixed lymphocyte reaction (MLR), $2 \times 10^{4}$ viable responder $\mathrm{T}$ cells/well were incubated with either $2 \times 10^{4}$ autologous or allogeneic irradiated (10000 R) EBVB or $10^{5}$ irradiated PBMC (3000 R) as stimulator cells. For mitogen stimulation, $2 \times 10^{4} \mathrm{~T}$ cells together with $10^{5}$ irradiated (3000 R) PBMC as feeder cells were stimulated with either PHA $20 \mu \mathrm{g} /$ $\mathrm{ml}$, Con A $2 \mu \mathrm{g} / \mathrm{ml}$ or both. Studies were also performed in the presence of $1 \mu \mathrm{g} / \mathrm{ml}$ indomethacin. Cells were incubated for $48 \mathrm{~h}$ in $5 \% \mathrm{CO}_{2}$ at $37^{\circ} \mathrm{C}$ and then pulsed with $0.5 \mu \mathrm{Ci}{ }^{3} \mathrm{H}$-thymidine/well. Cells were harvested $24 \mathrm{~h}$ later onto glass fibre filters using an automatic cell harvester (MASH, Microbiological Assoc Inc, Bethesda, MD), after which filters were counted in a liquid scintillation counter.

IL-2 ASSAY
$\mathrm{T}$ lymphocytes, $10 \% \mathrm{ml}$, were stimulated in the 
absence of accessory cells in U-bottomed microtitre plates with PHA $20 \mu \mathrm{g} / \mathrm{ml}$, PMA $25 \mathrm{ng} / \mathrm{ml}$, or a combination of PHA and PMA. After $24 \mathrm{~h}$, supernatants were harvested, two-fold serially diluted, and assayed for IL-2 using the IL-2 dependent murine cell line NK, as previously described..$^{1+15}$ One unit of IL-2 was defined as the reciprocal of the dilution of IL-2 resulting in a proliferative response which was $50 \%$ of the maximal response of $4 \times 10^{3}$ murine NK cells. Supernatant from the gibbon lymphoma line MLA 144 , which constitutively secretes IL-2, was used as a positive control. Variability of a single control run in triplicate is consistently less than $15 \%$ in this assay. Day to day variability is higher; consequently, all samples were run simultaneously.

$$
\% \text { specific lysis }=\frac{\mathrm{cpm} \text { release experimental group }-\mathrm{cpm} \text { spontaneous release }}{\mathrm{cpm} \text { after detergent lysis }-\mathrm{cpm} \text { spontaneous release }} \times 100
$$

\section{CELL DEPLETION}

To deplete Leu 7 and Leu 11b bearing cells from small intestinal lymphocyte lines, cells were incubated for 45 minutes at $4^{\circ} \mathrm{C}$ with Leu 7 and Leu $11 \mathrm{~b}$ monoclonal antibodies, washed twice, and then incubated at $37^{\circ} \mathrm{C}$ for 45 minutes with a $1: 10$ dilution of guinea pig complement (Pel Freeze, Brown Deer, WI). Control cell lines were treated with complement alone.

\section{Results}

T lymphocyte lines were grown successfully from each of the six consecutive individuals from whom duodenal biopsy specimens were obtained. After one to two days in culture, blast transformation and mononuclear cell migration out from tissue fragments was noted (Fig. 1). Examination of individual biopsy fragments for cell viability by acridine orange and ethidium bromide staining indicated cell variabilities ranging from $60-80 \%$. After 10 days, greater than $1.5 \times 10^{6}$ mononuclear cells could be harvested from two biopsies. Subsequent doubling time of these cells in culture was approximately five days. Data referring to phenotype include data from patients with coeliac disease. All functional data, however, refer to non-coeliac cell lines.

\section{CELL PHENOTYPE}

After six to 12 weeks in culture, small intestinal lymphocytes were predominantly $\mathrm{CD} 2, \mathrm{CD} 3$, and CD4 positive (Table 2). With the exception of line ALS, the intensity of CD8 staining was considerably less than that of CD4. One to $7 \%$ of cells expressed Leu 7 or CD16. Cell line ALS had the highest proportion of Leu 7 and CD16 positive cells, and a
CYTOTOXICITY

T lymphocytes were used 14 days after last exposure to mitogen and nine days after last exposure to interleukin 2. Target cells were radiolabelled by incubation at $37^{\circ} \mathrm{C}$ in $5 \% \mathrm{CO}_{2}$ for one hour in PBS containing $1 \mathrm{mCi} / \mathrm{ml}{ }^{51} \mathrm{Cr}$ sodium chromate (New England Nuclear Corp, Boston, MA). K562 was used as a human NK sensitive target. Raji and Daudi cell lines were used as NK resistant targets. Other targets included allogeneic and autologous EBVB prepared in our laboratory. Effector cells $\left(5 \times 10^{5}\right)$, or dilutions, were added in a $100 \mu \mathrm{l}$ volume to 96-well $\mathrm{U}$ bottomed microtitre plates after which $10^{4}{ }^{51} \mathrm{Cr}$ labelled targets in $100 \mu \mathrm{l}$ were added. After incubation for four hours at $37^{\circ} \mathrm{C}$ in $5 \% \mathrm{CO}_{2}$, specific lysis was calculated using the formula:

majority of ALS cells, expressed Leu 19. Some variability in phenotype was observed. This was particularly noted in the line ALS in which a large proportion of cells expressed CD8 at 12 weeks. It is worth noting, however, that with the exception of ALS, this protocol avoids excessive expansion of IL-2 dependent cytolytic cells.

\section{CYTOTOXICITY}

All four lines tested were cytotoxic for K562, and NK sensitive target line. ALS demonstrated substantial NK activity whereas, in three other lines, levels of cytotoxicity were low, but titrated with decreasing effector to target cell ratios (Fig. 2a). Further, in the two cases tested, cytotoxicity for K562 was abrogated by the depletion of Leu 7 and Leu $11 \mathrm{~b}$ positive cells (Fig. 2b). Daudi, an NK resistant cell line, was not killed by the intestinal cell lines (Fig. 2c), nor were the NK resistant cell line Raji or autologous or allogeneic EBV transformed B cells (data not shown).

\section{Table 2 Phenotype of intestinal T lymphocyte lines}

\begin{tabular}{|c|c|c|c|c|c|c|c|c|}
\hline \multirow{2}{*}{$\begin{array}{l}\text { Cell } \\
\text { line }\end{array}$} & \multirow{2}{*}{$\begin{array}{l}\text { Duration } \\
\text { in culture } \\
(w k)\end{array}$} & \multicolumn{7}{|c|}{ Cells expressing marker ( $\%)$} \\
\hline & & $C D 2$ & $C D 3$ & $C D 4$ & $C D 8$ & Leu 7 & $C D 16$ & Leu 19 \\
\hline $1 \mathrm{AH}$ & 6 & 89 & 90 & 90 & 31 & $3 \cdot 7$ & $2 \cdot 1$ & NT \\
\hline \multirow{2}{*}{$2 \mathrm{PR}$} & 6 & 91 & 97 & 84 & 28 & $2 \cdot 7$ & 1 & NT \\
\hline & 12 & NT & 89 & 75 & 47 & 2 & 1 & 6 \\
\hline \multirow[t]{2}{*}{$3 \mathrm{EJ}$} & 6 & 83 & 90 & 62 & 44 & 4 & 2 & NT \\
\hline & 12 & NT & 93 & 82 & 10 & 3 & 2 & 7 \\
\hline $4 \mathrm{BH}$ & 6 & NT & NT & 71 & 35 & NT & NT & NT \\
\hline $5 \mathrm{ROPE}$ & 6 & NT & NT & 82 & 26 & NT & NT & NT \\
\hline \multirow{2}{*}{6 ALS } & 6 & 82 & 93 & 56 & 55 & $7 \cdot 2$ & 7 & NT \\
\hline & 12 & NT & 89 & 18 & 85 & NT & NT & 60 \\
\hline
\end{tabular}

$\mathrm{NT}=$ not tested. 


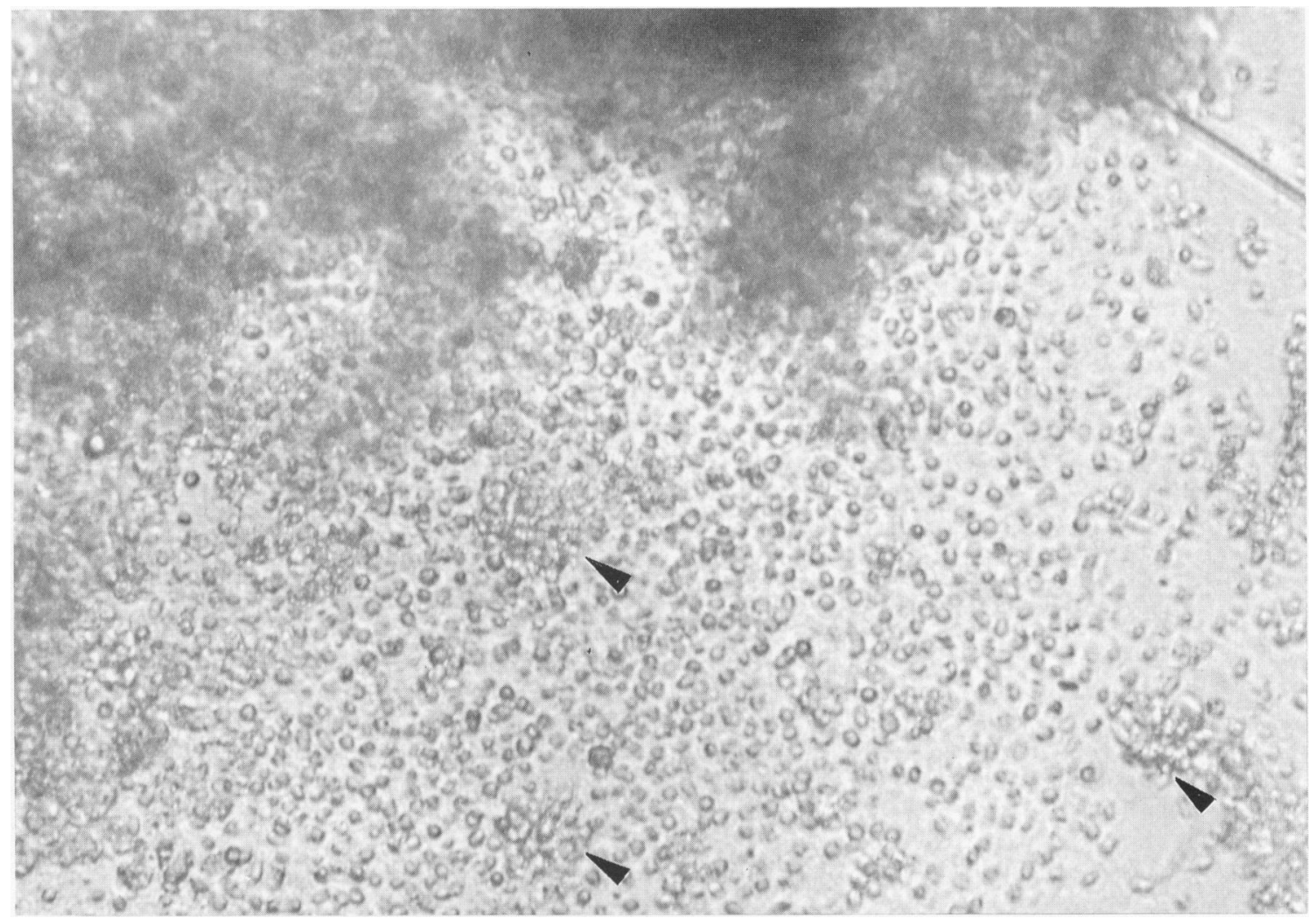

Fig. 1 Cell migration from a biopsy fragment after two days in culture with PHA, ConA and indomethacin. Clumps of blast cells (arrows) can be observed by phase contrast microscopy.

\section{PROLIFERATION}

Small intestinal lymphocytes proliferated in response to Con A or PHA. Further, the addition of indomethacin had little affect on either Con A or PHA stimulated proliferation of the cell lines. The addition of indomethacin to cultures, however, stimulated with both Con A and PHA resulted in a marked augmentation of thymidine incorporation (Fig. 3). In most cases, the $\mathrm{T}$ cell lines proliferated little if at all when HLA typed autologous EBVB, allogeneic EBVB (Table 3) or PBMC (data not shown) were used as stimulators in the MLR. Thus, no stimulation was seen in response to five of seven autologous or allogeneic EBVB, while low levels of proliferation were detected with EBVB stimulators from $\mathrm{AH}$ and YE which shared only HLA A24. The HLA typing of the cells is indicated in Table 4.

\section{IL-2 SECRETION}

Of four cell lines tested, all secreted IL-2 in response to a combination of PMA and PHA (Table 5). None secreted IL-2 in response to PMA alone. The ALS line, which contained a low proportion of $\mathrm{CD} 4$ cells
Table 3 Proliferation of intestinal $T$ cell lines in response to autologous and allogeneic stimulator cells

Source of autologous or allogeneic EBV transformed $B$ cells

$\begin{array}{lllllll}\text { Subject } & & & & & \\ A H & R P & A L S & Y E & W J G & D N & G M H\end{array}$

Source of

$\mathrm{T}$ cell line

PR

ALS

$\begin{array}{rrrrrrr}621 & 0 & 0 & 2483 & 0 & 0 & 0 \\ 724 & 0 & 0 & 3842 & 0 & 0 & 0 \\ 0 & 0 & 0 & 0 & 0 & 0 & 0 \\ 1842 & 0 & 0 & 4410 & 0 & 0 & 0\end{array}$

$2 \times 10^{+} \mathrm{T}$ cells/well were cultured with $2 \times 10^{4}$ irradiated autologous or allogeneic EBVB as described in Methods. Results are expressed as $\mathrm{cpm}$ ' $\mathrm{H}$-thymidine incorporated with backgrounds subtracted. Backgrounds for cultures containing T cells alone ranged from 68 to $330 \mathrm{cpm}$ and backgrounds for cultures containing EBV transformed $B$ cells alone range from 246 to 1356 . Results are means of triplicate cultures. No proliferation was seen when the same $T$ cells were stimulated with irradiated (30)0 R) autologous or allogeneic PBMC In controls, AH. EJ, PR, and ALS T cells stimulated with PHA alone $(10 \mu \mathrm{g} / \mathrm{ml})$ yielded $8375,15573,12457$, and $18010 \mathrm{cpm}$ respectively. 

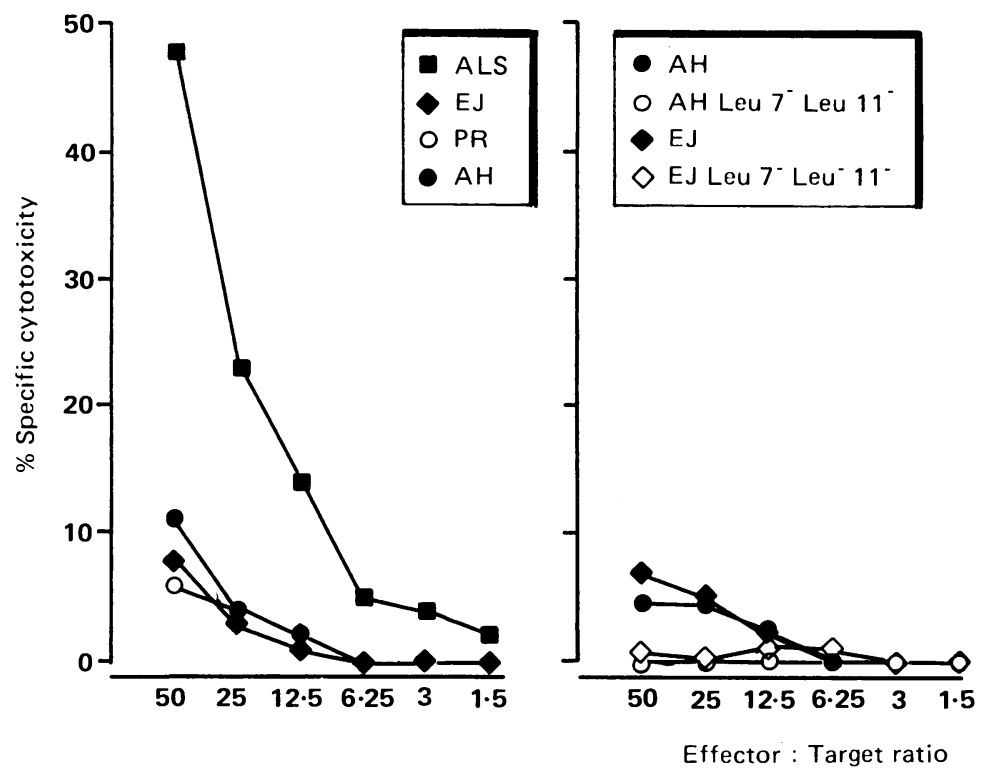

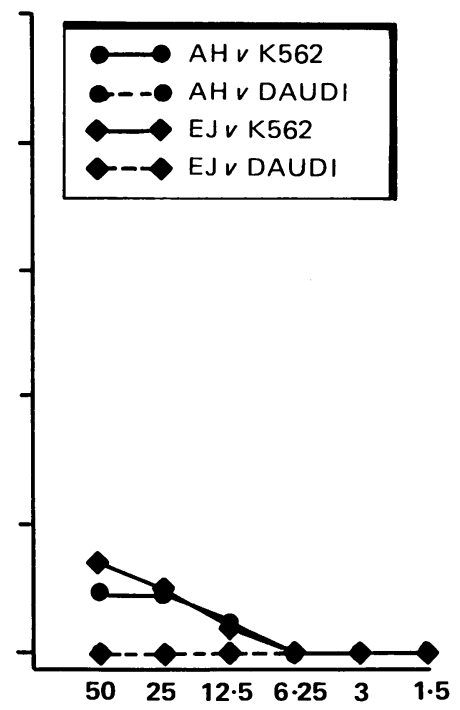

Fig. 2 (a) Specific cytotoxicity of four intestinal lymphocyte lines for K562, and NK sensitive target cell line at varying effector: target ratios. (b) Specific cytotoxicity of lines $A H$ and EJ for K562, the NK sensitive target, before and after depletion of Leu 7 and Leu $11 \mathrm{~b}$ (CD 16) cells. (c) Specific cytotoxicity of AH and EJ cell lines for K562 and for the NK resistant target, Daudi. Similar results were obtained using the NK-resistant cell line, Raji, and EBV transformed B lymphoblasts as targets (data not shown).

(Table 2), secreted little IL-2. It is notable that these experiments were performed in the absence of accessory cells.

\section{Discussion}

Methods for the longterm cultivation of $\mathrm{T}$ lymphocyte lines from human small intestine will provide a powerful tool to study the intestinal immune system

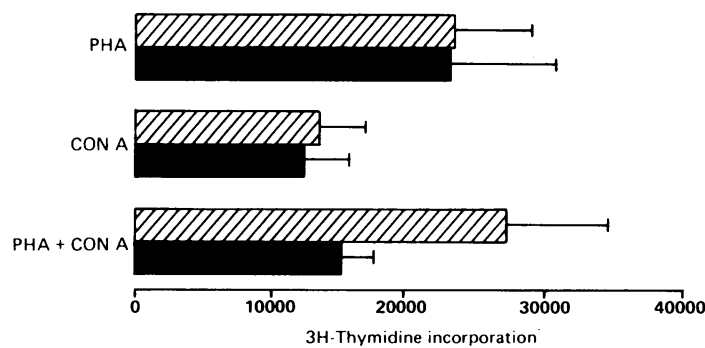

Fig. 3 Tritiated-thymidine incorporation in $T$ cell lines stimulated with PHA $20 \mu \mathrm{g} / \mathrm{ml}$, Con $A 2 \mu \mathrm{g} / \mathrm{ml}$ or a combination of PHA and ConA. Solid bars are cultures without indomethacin and hatched bars are cultures with indomethacin $1 \mu \mathrm{g} / \mathrm{ml}$. Data are expressed as CPM and horizontal bars represent the SEM. Proliferation induced by PHA and ConA combined is significantly augmented by indomethacin ( $p<0 \cdot 05 ;$ Mann Whitney one-tailed test). and its role in disease. Using mitogen stimulated proliferation of lymphocytes in small intestinal endoscopic biopsies, we have been able to develop several $\mathrm{T}$ cell lines which can be maintained in culture for at least 12 weeks. As intraepithelial T lymphocytes are predominately $\mathrm{CD} 8$ positive, and fail to proliferate in response to mitogens, ${ }^{16} 17$ it is probable that the majority of lymphocytes in this culture system originate from the lamina propria. This is supported by the finding that five of six of the $T$ cell lines contained predominantly $\mathrm{CD} 4$ positive $\mathrm{T}$ lymphocytes, a phenotype that predominates in the lamina propria. ${ }^{14}$

Table 4 HLA type of donors of responder and stimulator cells

\begin{tabular}{llcll}
\hline Subject & $A$ & $B$ & $D R$ & $D O$ \\
\hline AH & 324 & 735 & 12 & W1 - \\
PR & 111 & 835 & 13 & ND \\
ALS & $2-$ & $8-$ & 35 & W3 - \\
EJ & 328 & 1459 & $6-$ & ND \\
YE & 124 & $8-$ & 33 & W2 W2 \\
WJG & 211 & 744 & 27 & W1 W2 \\
GMH & $2-$ & 539 & 26 & W1 - \\
DN & 311 & 78 & ND & ND \\
\hline
\end{tabular}

ND - not determined; HLA DQ types were determined by microcytotoxicity, and for some lines by restriction fragment length polymorphism analysis. 
Table $5 \quad I L-2$ secretion by intestinal $T$ cell lines

\begin{tabular}{|c|c|c|c|}
\hline \multirow[b]{2}{*}{ T cell line } & \multicolumn{3}{|l|}{ Stimulus } \\
\hline & PHA $20 \mu \mathrm{g} / \mathrm{ml}$ & $P M A 25 \mathrm{ng} / \mathrm{ml}$ & $\begin{array}{l}\text { PHA }(20 \mu \mathrm{g} / \mathrm{ml})+ \\
\text { PMA }(25 \mathrm{ng} / \mathrm{ml})\end{array}$ \\
\hline $\mathrm{AH}$ & 0 & 0 & 66 \\
\hline PR & 0 & 0 & 70) \\
\hline ALS & 0 & 0 & 2 \\
\hline EJ & 5 & 0 & 26 \\
\hline
\end{tabular}

IL-2 secretion is expressed as units/ml.

T cell lines have been developed previously from other tissues, including kidney, ${ }^{18}{ }^{14}$ liver, ${ }^{, 11}$ cerebrospinal fluid, ${ }^{21}$ and skin..$^{22} 23$ In several cases, mitogens have been used ${ }^{21124}$ to expand such cell populations. Our strategy was to avoid IL-2 stimulation at the initiation of culture because it might result in the selective expansion of populations of IL-2-responsive non-MHC restricted cytolytic cells. ${ }^{25}$ In contrast, the use of PHA to expand T cell populations does not appear to interfere with the ability to subsequently develop antigen specific helper $\mathrm{T}$ lymphocyte lines. ${ }^{26-2 x}$ Con A stimulation was used here, however, may induce low levels of CD8 expression on CD4 positive cells,,$^{29}$ resulting in a dual positive subpopulation.

The definition of NK cells and their distinction from lymphokine-activated killer cells (LAK) has been controversial. ${ }^{31-33}$ Lanier et al have suggested that the term 'NK cell' be applied to a specific cell lineage lacking CD3 and expressing CD16. ${ }^{.4}$ Others have suggested, however, that all cells that are cytotoxic for NK sensitive targets should be labelled 'NK cells' ${ }^{35}$ In some studies, neither cells expressing NK markers ${ }^{34}$ nor cells exhibiting NK cytolytic activity ${ }^{412}$ were found in intestinal lymphocytes. Leu 7, Leu 11, and Leu 19 positive cells, however, have been reported in the intestine in other studies. ${ }^{4637}$ Moreover, low but consistent killing of NK-sensitive targets has been demonstrated using freshly isolated intestinal lymphocytes at a high lymphocyte:target ratio. Whichever definition of NK cells is used, the current studies show small numbers of cells expressing phenotypic markers associated with NK cells and low levels of NK killing in lymphocyte lines derived from the small intestine. Finally, we note that in peripheral blood, a small population of CD3 + Leu 19+ cells can mediate non-MHC restricted cytotoxicity. ${ }^{33}$ It may be that the high levels of K562 killing with ALS reflect cells with that phenotype in the ALS line.

The CD4 positive small intestinal lymphocyte lines developed herein secreted IL-2, consistent with their role as T helper cells. In this regard, two classes of murine $T$ helper cells can be distinguished based on the lymphokines they produce.$^{37}$ One class, termed type $1 \mathrm{~T}$ helper cells, produces IL-2 and gamma interferon, whereas the second class termed type $2 \mathrm{~T}$ helper cells, produces IL-4 and IL-5. ${ }^{1537}$ As IL-5 alone and in combination with IL-4 is important in regulating the expression of the IgA class, ${ }^{15}$ it will be important to further characterise the lymphokine products of the $\mathrm{T}$ helper cell populations in the small intestinal mucosa.

Two points warrant comment regarding the growth and proliferation of the small intestinal $\mathrm{T}$ cell lines. First, the addition of indomethacin to Con $\mathrm{A}$ and PHA stimulated small intestinal $T$ cell lines augmented their proliferation as much as two-fold, suggesting that it significantly augments the growth of these cell lines by inhibiting prostaglandin E2 secretion. ${ }^{.7}{ }^{38}$ Second, the small intestinal $\mathrm{T}$ cell lines exhibited little or no proliferation in an autologous or allogeneic MLR, whereas freshly isolated intestinal mononuclear cells have been reported to proliferate in a MLR. ${ }^{34}$ We have not explored the mechanism responsible for this difference. It is clear, however, at a technical level, that our method and those used to isolate cells from surgical specimens differ markedly.

Tissue derived lines have provided important functional information regarding local $\mathrm{T}$ lymphocyte function. T cell lines derived from the skin lesions of individuals with lepromatous leprosy suppressed mitogen driven $\mathrm{T}$ lymphocyte proliferation in an antigen specific HLA restricted fashion..$^{22} \mathrm{~T}$ cell lines derived from individuals with tuberculoid leprosy do not show suppression, suggesting a polarisation in the immune response at the level of the $T$ cell. $T$ cell lines derived from renal allograft biopsies are cytolytic for donor targets. ${ }^{18} 14$ This cytolysis is HLA restricted. Finally, in studies done using $T$ cell lines derived from individuals with hepatitis $B$, antigen specific help for the production of antibodies to hepatitis $\mathrm{B}$ core antigen was observed..$^{34}$ In diseases in which a specific antigen is implicated, $T$ cell clones may be useful for mapping relevant antigen determinants. ${ }^{26+1)+1}+3$ The ability to culture human intestinal $\mathrm{T}$ lymphocytes should permit the characterisation in more detail of the normal phenotypic and functional properties of these cells. Furthermore, the ability to utilise cells derived from endoscopic biopsies should permit a fuller understanding of the immunological mechanisms involved in intestinal disease in patients who are not undergoing surgical resection.

This work was supported by NIH grant DK35108. DK was a recipient of a John E. Fogarty International Fellowship. The authors wish to thank Dr R Langman for supplying the K562 cells line, Dr I Royston for the Raji and Daudi lines, and Dr S Swain for the NK cell line. We thank Ms D Sagall and Ms Lisa Webbs for preparation of the manuscript. 


\section{References}

1 Selby WS, Janossy G, Bofill M, Jewell DP. Intestinal lymphocyte subpopulations in inflammatory bowel disease: An analysis by immunohistological and cell isolation techniques. Gut 1984; 25: 32-40.

2 Kelly J, O'Farrelly C, O'Mahony C, Weir DG, Feighery C. Immunoperoxidase demonstration of the cellular composition of the normal and coeliac small bowel. Clin Exp Immunol 1987; 68: 177-88.

3 Cerf-Bensussan N, Schneeberger EE, Bhan AK. Immunohistologic and immunoelectron microscopic characterization of the mucosal lymphocytes of human small intestine by the use of monoclonal antibodies. J Immunol 1983; 130: 2615-22.

4 James SP, Fiocchi C, Graeff AS, Strober W. Phenotypic analysis of lamina propria lymphocytes. Predominance of helper-inducer and cytolytic $\mathrm{T}$ cell phenotypes and deficiency of suppressor-inducer phenotypes in Crohn's disease and control patients. Gastroenterology 1986; 91: 1483-9.

5 Jacobson S, Richert JR, Biddison WE, Satinski A, Hartzman RJ, McFarland HF. Measles virus-specific $\mathrm{T} 4+$ human cytotoxic $\mathrm{T}$ cell clones are restricted by Class II HLA antigens. $J$ Immunol 1984; 133: 756-7.

6 Fleischer B, Schnezenulier H, Wagner H. Function of the CD4 and CD8 molecules on human cytotoxic T lymphocytes: regulation of $\mathrm{T}$ cell triggering. J Immunol 1986; 136: 1625-8.

7 Bookman MA, Bull DM. Characteristics of isolated intestinal mucosal lymphoid cells in inflammatory bowel disease. Gastroenterology 1979; 77: 503-10.

8 Bartnik W, ReMine SG, Chiba M, Thayer WR, Shorter $\mathrm{RG}$. Isolation and characterization of colonic intraepithelial and lamina proprial lymphocytes. Gastroenterology 1980; 78: 976-85.

9 Fiocchi C, Tubbs RR, Youngman KR. Human intestinal mucosal mononuclear cells exhibit lymphokineactivated killer cell activity. Gastroenterology 1985; 88: 625-37.

10 Targan S, Britvan L, Kendal R, Vimadalal S, Soll A. Isolation of spontaneous and interferon inducible natural killer like cells from human colonic mucosa: Lysis of lymphoid and autologous epithelial target cells. Clin Exp Immunol 1983; 54: 14-22.

11 Gibson RP, Jewell DP. The nature of the natural killer cell of human intestinal mucosa and mesenteric lymph node. Clin Exp Immunol 1985; 61: 160-8.

12 McDermott RP, Franklin GD, Jenkins KM, Kodner IJ, Nash GS, Weinrieb IJ. Human intestinal mononuclear cells. 1. Investigation of antibody-dependent lectin induced and spontaneous cell-mediated cytotoxic capabilities. Gastroenterology 1980; 78: 47-56.

13 Howell MD, Austin RK, Kelleher D, Nepom GT, Kagnoff MF. An HLA-D region restriction fragment length polymorphism associated with celiac disease. J Exp Med 1986; 164: 333-8.

14 Gillis S, Ferm MM, Ou W, Smith KA. T cell growth factor: Parameters of production and a quantitative microassay for activity. J Immunol 1978; 120: $2027-$ 32.

15 Murray PD, McKenzie DT, Swain SL, Kagnoff MF. Interleukin 5 and Interleukin 4 produced by Peyer's patch $\mathrm{T}$ cells selectively enhance Immunoglobulin A expression. J Immunol 1987; 139: 2669-75.

16 Greenwood JH, Austin LL, Dobbins WO. In vitro characterization of human intestinal intraepithelial lymphocytes. Gastroenterology 1983; 85: 1023-35.

17 Ebert EC, Roberts AI, Brolin RE, Raska K. An examination of the low proliferative capacity of jejunal intraepithelial lymphocytes (IEL). Clin Exp Immunol 1986; 65: 148-57.

18 Miceli C, Metzgad RS, Chedid M, Ward F, Finn OJ. Long term culture and characterization of alloreactive T-cell infiltrates from renal needle biopsies. Hum Immunol 1985; 14: 295-304.

19 Mayer TG, Fuller AA, Fuller TC, Lazarovitz AI, Boyle LA, Kurnick JT. Characterization of in vitro activated, allospecific $\mathrm{T}$ lymphocytes propagated from human renal allograft biopsics undergoing rejection. $J$ Immunol 1985; 134: 258-62.

20 Ferrari C, Penna A, Sansoni P, Giuberti T, Fiaccadori F. Clonal analysis of intrahepatic $T$ lymphocytes in chronic active hepatitis. Hepatology 1986; 3: 386-91.

21 Santoli D, Aefrertus EC, Sandberg-Wollheim M, Francs MK, Koprowski H. Phenotypic and functional characterization of $\mathrm{T}$-cell clones derived from cerebrospinal fluid of multiple sclerosis patients. J Immunol 1984; 132: 2386-92.

22 Modlin RL, Mehra V, Wong L, et al. Suppressor T lymphocytes from lepromatous leprosy skin lesions. J Immunol 1986; 137: 2831-4.

23 Ottenhoff THM, Elterink BG, Klatser PR, de Vries RRP. Cloned suppressor $T$ cells from a lepromatous leprosy patient suppress Mycobacterium leprac reactive helper T cells. Nature $1986 ; 322: 462-4$.

24 Britten V. Hudson L. Isolation and characterization of human T-cell lines from a patient with Chagas disease. Lancet 1985; ii: 637-9.

25 Baker PE, Gillis S, Smith KA. Monoclonal cytolytic T cell. J Exp Med 1979; 149: 273-8.

26 Sinigaglia F, Pink JRL. Human T lymphocyte clones specific for malaria (Plasmodium falciparum) antigens. EMBO J 1985; 4: 3819-22.

27 Van de Griend RJ, Van Krimpen BA, Bol SJL, Thompson A, Bolhuis RLH. Rapid expansion of human cytotoxic $\mathrm{T}$ cell clones: Growth promotion by a heatlabile serum component and by various types of feeder cells. J Immunol Methods 1984; 66: 285-98.

28 Haanen JB, Ottenhoff TH, Voordouw A, et al. HLA Class II restricted mycobacterium Leprac-reactive T-cell clones from leprosy patients established with minimal requirement for autologous mononuclear cells. Scand J Immunol 1986; 23: 101-8.

29 Blue ML, Daley JF, Levine H, Schlossman SF. Coexpression of $\mathrm{T} 4$ and $\mathrm{T} 8$ on peripheral blood $\mathrm{T}$ cells demonstrated by two-color fluorescence flow cytometry. J Immunol 1985; 134: 2281-6.

30 Timonen T, Ortaldo JR, Herberman RB. Characteristics of human large granular lymphocytes (LGL) and relationship to natural killer and $\mathrm{K}$ cells. J Exp Med 1981; 153: 569-82.

31 Lanier LL, Le AM, Phillips JH, Warner NL, Babcock GF. Subpopulations of human natural killer cells defined by expression of the Leu 7 (HNK-1) and Leu 11 (NK-15) antigens. J Immunol 1983; 131: 1789-96. 
32 Lanier LL, Phillips JH. Evidence for three types of human cytotoxic lymphocytes. Immunol Today 1986; 7: 132-4.

33 Lanier LL, Le AM, Civin CI, Loken MR, Phillips JH. The relationship of CD 16 (Leu 11) and Leu 19 (NKH.1) antigen expression on human peripheral blood NK cells and cytotoxic T lymphocytes. J Immunol 1986; 136: 4480-6.

34 Lanier LL, Phillips JH, Hackett J, Tutt M, Kumar V. Natural killer cells: definition of a cell type rather than a function. J Immunol 1986; 137: 2735-9.

35 Reynolds CW, Ortaldo JR. Natural killer activity: the definition of a function rather than a cell type. Immunol Today 1987; 7: 172-4.

36 Rodgers VD, Fassett R, Kagnoff MF. Abnormalities in intestinal mucosal $\mathrm{T}$ cells in homosexual populations including those with the lymphadenopathy syndrome and AIDS. Gastroenterology 1986; 90: 552-8.

37 Mosmann TR, Cherwinski H, Bond MW, Giedlin MA, Coffman RL. Two types of murine helper T cell clones. I. Definition according to profile of lymphokine activities and secreted proteins. J Immunol 1986; 136: 234857.
38 Rappaport RS, Dodge GR. Prostaglandin E inhibits the production of human interleukin 2. J Exp Med 1982; 155: $943-8$.

39 MacDermott RP, Bragdon MJ, Jenkins KM, Franklin SD, Shedlofsky S, Kodner IJ. Human intestinal mononuclear cells. II. Demonstration of a naturally occurring subclass of T cells which respond in the allogeneic mixed leucocyte reaction but do not effect cell-mediated lympholysis. Gastroenterology 1984; 80: 748-57.

40 Ferrari C, Mondelli MV, Penna A. Fiaccadori F, Chisari FV. Functional characterization of cloned intrahepatic Hepatitis B virus nucleo-protein specific helper T cell lines. J Immunol 1987; 139: 539-45.

41 Mills KHG, Skehel JJ, Thomas DB. Extensive diversity in the recognition of influenza virus hemagluttinin by murine T helper clones. J Exp Med 1986; 163: 1477-90.

42 Ottenhof TH, Klatser PR, Ivanyi J, Elferink DG, de Wit MY, de Vries RR. Mycobacterium Leprae-specific protein antigens defined by cloned human helper T cells. Nature 1986; 319: 66-8.

43 Shanahan F, Brogan M, Targan S. Human mucosal cytotoxic effector cells. Gastroenterology 1987; 92: 1951-7. 